\title{
RESEARCH ARTICLE \\ Effect of Prey Density on Biology and Foraging Potential of Mallada boninensis (Okamato) (Neuroptera: Chrysopidae)
}

\author{
Elango $\mathbf{K}^{\mathbf{1}^{*}}$, Jeyarajan Nelson $\mathbf{S}^{2}$ and Sridharan $\mathbf{S}^{2}$ \\ ${ }^{1}$ Department of Agricultural Entomology, Kumaraguru Institute of Agriculture, Erode - 638315 \\ ${ }^{2}$ Department of Agricultural Entomology, Tamilnadu Agricultural University, Coimbatore- 641003
}

\begin{abstract}
The present study aimed to evaluate the effect of prey density on the biology and functional response of green lacewing, Mallada boninensis (Okamato) (Neuroptera: Chrysopidae). Newly emerged larvae of $M$. boninensis were fed 20, 30, 40, 50, 60, 70, 80, 90 and 100 fresh eggs of Corcyra cephalonica (Lepidoptera: Gelechiidae) in plastic vials. It was observed that the prey density had a significant effect on the positive consumption rate, development, and fecundity of $M$. boninensis. In general, maximum consumption with shortest developmental time, maximum fecundity, and most extended adult longevity was observed as prey density increased. The predatory potential was high when the prey density was raised. The daily predation rate of $M$. boninensis increased slowly during the first two instars and reached its peak in the third larval instar. The results indicated that $M$. boninensis feeding potential and developmental period might vary from 6.00 to 11.33 days based on food density and having a difference in per day consumption. The 100 Corcyra eggs/day treatment had the highest egg intake of 87.88 eggs per day, followed by 90 eggs/day (79.33 eggs) and 80 egg day $^{-1}$ (69.75 eggs).
\end{abstract}

Keywords: Corcyra cephalonica; Chrysopidae; Prey density; Lacewing; Mallada boninensis

\section{INTRODUCTION}

There are several natural enemies of insect pests which co-exist with them in the different ecosystems. Amongst a very complex network of bio agents, the Chrysopid is known to be the most effective predator. Chrysopids are commonly termed green lacewings. Chrysopids have a tremendous potential to consume pests of crops. Because of their large geographical distribution, broad habitats with a high relative frequency of occurrence, strong seeking ability, and ease of laboratory rearing, C. zastrowi sillemi (Esben-Peterson) and Mallada boninensis (Okamoto) (Neuroptera: Chrysopidae) are the most thoroughly researched species of Chrysopids. Green lacewings are one of the most efficient generalist predators employed in biological control (McEwen et al., 2001). Adults are generally not predatory and feed on nectar, pollen or honeydew while a few of them are predatory (Coppel and Mertins, 1977). Amongst the Mallada spp., M. boninensis, $M$. basalis, $M$. aster, and $M$. desjardinsi are essential as these are found to be potential predators of aphids, leaf miners, psylla, blackfly, and whitefly (Syed et al., 2008; Riddick, 2009). In recent years use of green lacewing species has been recommended for the IPM programme (Nehare et al., 2004). They can be successfully reared on eggs of Corcyra cephalonica Stainton in the laboratory.

The predation phenomena of the $M$. boninensis, are sometimes not as simple as mentioned above but change with varying prey densities. It has been observed with many insects and small animal predators that when prey population increased, prey consumption also increased and consumption rate is the function of food density (Elango and Sridharan,2018). Such a changing behavior ultimately affects the predator's release pattern in a bio-control program and needs to be studied for better understanding under different ecosystems. Therefore, a study was designed to evaluate the predation rate of laboratory-reared $M$. boninensis, on Corcyra eggs with the following objectives: (i) to determine the predation rate of all larval instars under nine prey density levels and (ii) to study the effect of prey density on the biology of $M$. boninensis.

\section{MATERIAL AND METHODS}

\section{Culture of Rice moth, Corcyra cephalonica (Stainton)}

Rice moth, C. cephalonica has been widely used as an efficient alternative host for the mass rearing of 
many biocontrol agents. Bajra (Pennisetum glaucum L.)grains were coarsely milled and broken into 2-3 pieces in a milling machine. The broken grains are heat sterilized at $100^{\circ} \mathrm{C}$ for 1 hour to eliminate the residual population of stored product insects viz., Rhizopertha dominica, Sitotroga cerealella, Tribolium castaneum and fungal contaminants. Upon sterilization, the grains were cooled under the fan in a clean area. The grains were then transferred to plastic basins @ 2.5 kg/basin. Groundnut kernel in required quantity was broken using a pounding machine, a mechanical blender, or a machine (domestic mixer). After that, $100 \mathrm{~g}$ of the broken kernel was placed in each basin and well mixed by hand. The materials were well combined after adding dry yeast (Bakers) and wettable sulphur at a rate of $5 \mathrm{~g} /$ basin. This was followed by a spray of $10 \mathrm{~mL}$ of 0.01-0.05 percent streptomycin sulphate and mixing the contents. Corcyra larvae are reared in the bajra medium.

The eggs used to start a Corcyra colony must be devoid of pollutants such as moth scales and broken limbs, and they must not be exposed to UV radiation. The number of trays that can be infected with eggs is determined by measuring the volume of overnight deposited eggs collected. A cc of eggs is estimated to contain between 16000 and 18000 eggs. Cumbu medium with optimal amounts of Corcyra eggs Corcyra eggs infest $0.5 \mathrm{cc}$ of water each basin. After that, the basins were covered with a clean khada fabric and secured with rubber fasteners. After the eggs have been infested for 28-30 days, the adults emerge. On the inside of the khada fabric, the grownups may be seen. They are either aspirated or collected using a mechanical moth catcher with specimen tubes. The entire procedure takes place under a mosquito net tent. This prevents the moths from escaping in significant numbers, which, if left unchecked, may move to the storage area and damage the grains by laying eggs. 1000 pairs of moths per drum were transported to the oviposition drum at a time. The oviposition drums were constructed of galvanised iron and measure 30 $x 20 \mathrm{~cm}$. The drums were supported by tripod frames with $5 \mathrm{~cm}$-high legs. Wire meshes were installed in the bottoms of the drums to allow for egg collecting. Adults were fed a honey solution comprising feed. Adult feed was made by combining $50 \mathrm{~mL}$ honey with $50 \mathrm{~mL}$ water and 5 vitamin E pills (Evion). The eggs were laid in great quantities by the moths.

Along with the eggs, scales and shattered limbs were discovered in higher proportions. The eggs were carefully rolled on filter paper to another container to clean the collecting. The eggs were quantified in measuring cylinders and used to build up the stocks and natural enemy production.

\section{Mass culturing of Mallada boninensis}

Grubs were reared in G.I. round basins $(28 \mathrm{~cm}$ dia) @250 larvae/basin covered with khada cloth. The eggs of Corcyra cephalonica were given as feeding material for the larvae in the laboratory. In ten days, the $M$. boninensis larvae pupate into round white-colored silken cocoons. The cocoons were collected with fine brush and transferred into 1 litre plastic container with a wire mesh window for emergence of adults. The adults were collected daily and transferred to pneumatic glass troughs or G.I. round troughs $(30 \mathrm{~cm} \times 12 \mathrm{~cm})$. Before allowing the adults, the rearing troughs were wrapped inside with a brown sheet that acted as egg receiving card. About 250 adults (60\% females) were allowed into each trough and covered with white nylon or georgette cloth secured by a rubber band. Three bits of foam sponge (2 sq.in) dripped in water were kept above the nylon cloth cover. Besides, an artificial protein rich diet (yeast, fructose, honey, Proteinex ${ }^{R}$, and water in the ratio 1:1:1:1) was provided in semisolid paste form in three spots on the cloth outside. The adults were collected daily and allowed into fresh rearing troughs with fresh food. From the old troughs, the brown paper sheets and $M$. boninensis eggs were removed and used to maintain a culture of green lacewing.

\section{Prey density on biology of M. boninensis}

The experiment was designed in a completely randomized (CRD) design. There were nine (food densities) treatments, viz., 20, 30, 40, 50, 60, 70, 80, 90, 100 Corcyra eggs/grub/day. Each treatment was replicated thrice. Each replication has three samples (Mallada grubs). Freshly harvested $M$. boninensis eggs were placed in $9 \mathrm{~cm}$ Petri dish sealed with parafilm to avoid desiccation and were observed daily. Newly emerged larvae of $M$. boninensis were transferred into plastic vials with counted number of fresh Corcyra eggs for each food density/ replication. The larvae of $M$. boninensis were transferred carefully to the capsules with the help of fine camel hair brush. Vials contents were observed under stereo microscope every day to determine the number of unconsumed eggs and any change in larval biology. The numbers of unconsumed eggs were subtracted from the total number of offered eggs (prey density) and data were recorded on a daily basis. Biological parameters like the duration of development of each larval instar, pupation, adult emergence, and mortality occurring in each treatment was recorded daily in all prey densities. After pupation, each pupa was observed for adult emergence and recorded. The emerging adults were transferred to G.I. round troughs $(30 \mathrm{~cm}$ $\times 12 \mathrm{~cm}$ ). The adults were fed daily on a thick viscous solution of water + honey + yeast. The adult's basins were observed every $24 \mathrm{~h}$ for egg-laying 


\section{Statistical analysis}

The data collected under laboratory experiments in completely randomized design were analyzed using analysis of variance (ANOVA) using AGRES 3.01 and AGDATA software. Data in the form of numbers were transformed to square root values and those in numbers were transformed to and analyzed. The mean values of the treatments were compared using DMRT at 5 per cent level of significance

\section{RESULTS AND DISCUSSION}

\section{Effect of food density on Mallada boninensis consumption}

The larvae of $M$. boninensis responded to increasing prey densities with increasing food consumption and older larval stages displayed a higher rate of predation than younger ones (Fig 1). The consumption rate increased progressively during each day. Maximum the $M$. boninensis fed 703.00 \pm 0.18 Corcyra eggs within minimum developmental period of $6.00 \pm 0.01$ days in the 100 eggs/day treatment. When the intake rate was reduced (173.67 \pm 0.07 Corcyra eggs) in the low number of eggs per treatment (20 eggs/day), the developmental time was increased by $11.33 \pm 0.02$ days. ( Table. 1). The results indicated that $M$. boninensis feeding potential and developmental period may vary $(6.00 \pm 0.01$ to $11.33 \pm 0.02$ days $)$ based on food density and the difference in per day consumption. Maximum consumption $87.88 \pm 0.01$ eggs/ day were observed in 100 Corcyra eggs/day treatment followed by 90 eggs/day (79.33 \pm 0.05 eggs) and $80 \mathrm{egg} \mathrm{day}^{-1}$ (69.75 \pm 0.03 eggs). Hassanpour et al. (2009) who studied the functional response of three larval instars of $C$. carnea on adult females of $T$. urticae. Results of the present studies revealed that the larvae of $M$. boninensis, especially the last instar, have a good predation potential. Its larger size facilitated its increased dietary requirement, resulting in more prey consumption than second and first instars. These results were in accordance with Klingen et al. (2009) who studied the predation rate of $M$. boninensis on eggs and first instar larvae of the lepidopterous species Mamestra brassicae (L.) including the prey's influence on survival and development. In both cases, the daily predation rate of $C$. carnea increased slowly during the first two instars and reached a peak in the third larval instar. During the third instar, $87 \%$ and $85 \%$ of the total numbers of $M$. brassicae eggs and larvae were consumed.

Table 1. Effect of food density on duration of grub, pupal and adult periods of Mallada boninensis

\begin{tabular}{|c|c|c|c|c|c|c|}
\hline $\begin{array}{l}\text { Treatments } \\
\text { (Eggs) }\end{array}$ & $\begin{array}{l}\text { First instar } \\
\text { (Days) }\end{array}$ & $\begin{array}{l}\text { Second instar } \\
\text { (Days) }\end{array}$ & $\begin{array}{l}\text { Third instar } \\
\text { (Days) }\end{array}$ & $\begin{array}{l}\text { Pupal period } \\
\text { (Days) }\end{array}$ & $\begin{array}{c}\text { Developmental period } \\
\text { (Days) }\end{array}$ & $\begin{array}{l}\text { adult longevity } \\
\text { ( Days) }\end{array}$ \\
\hline 20 & $\begin{array}{c}3.67 \\
(1.92)\end{array}$ & $\begin{array}{c}3.00 \\
(1.73)\end{array}$ & $\begin{array}{c}4.67 \\
(2.16)\end{array}$ & $\begin{array}{c}9.33 \\
(3.05)\end{array}$ & $\begin{array}{l}20.67 \\
(4.55)\end{array}$ & $\begin{array}{c}2.33 \\
(1.53)\end{array}$ \\
\hline 30 & $\begin{array}{c}3.67 \\
(1.92)\end{array}$ & $\begin{array}{c}3.00 \\
(1.73)\end{array}$ & $\begin{array}{c}4.33 \\
(2.08)\end{array}$ & $\begin{array}{c}8.33 \\
(2.89)\end{array}$ & $\begin{array}{l}19.33 \\
(4.40)\end{array}$ & $\begin{array}{c}4.67 \\
(2.16)\end{array}$ \\
\hline 40 & $\begin{array}{c}3.33 \\
(1.82)\end{array}$ & $\begin{array}{c}2.33 \\
(1.53)\end{array}$ & $\begin{array}{c}4.00 \\
(2.00)\end{array}$ & $\begin{array}{c}8.67 \\
(2.94)\end{array}$ & $\begin{array}{l}18.33 \\
(4.28)\end{array}$ & $\begin{array}{c}5.67 \\
(2.38)\end{array}$ \\
\hline 50 & $\begin{array}{c}3.33 \\
(1.82)\end{array}$ & $\begin{array}{c}2.33 \\
(1.53)\end{array}$ & $\begin{array}{c}3.67 \\
(1.92)\end{array}$ & $\begin{array}{c}8.00 \\
(2.83)\end{array}$ & $\begin{array}{l}17.33 \\
(4.16)\end{array}$ & $\begin{array}{c}7.67 \\
(2.77)\end{array}$ \\
\hline 60 & $\begin{array}{c}3.00 \\
(1.73)\end{array}$ & $\begin{array}{c}2.33 \\
(1.53)\end{array}$ & $\begin{array}{c}3.33 \\
(1.82)\end{array}$ & $\begin{array}{c}7.67 \\
(2.77)\end{array}$ & $\begin{array}{l}16.33 \\
(4.04)\end{array}$ & $\begin{array}{c}8.00 \\
(2.83)\end{array}$ \\
\hline 70 & $\begin{array}{c}3.00 \\
(1.73)\end{array}$ & $\begin{array}{c}2.33 \\
(1.53)\end{array}$ & $\begin{array}{c}3.33 \\
(1.82)\end{array}$ & $\begin{array}{c}6.33 \\
(2.52)\end{array}$ & $\begin{array}{l}15.00 \\
(3.87)\end{array}$ & $\begin{array}{c}8.33 \\
(2.89)\end{array}$ \\
\hline 80 & $\begin{array}{c}3.00 \\
(1.73)\end{array}$ & $\begin{array}{c}2.33 \\
(1.53)\end{array}$ & $\begin{array}{c}2.67 \\
(1.63)\end{array}$ & $\begin{array}{c}6.00 \\
(2.45)\end{array}$ & $\begin{array}{l}14.00 \\
(3.74)\end{array}$ & $\begin{array}{c}9.00 \\
(3.00)\end{array}$ \\
\hline 90 & $\begin{array}{c}2.67 \\
(1.63)\end{array}$ & $\begin{array}{c}2.00 \\
(1.41)\end{array}$ & $\begin{array}{c}2.33 \\
(1.53)\end{array}$ & $\begin{array}{c}5.00 \\
(2.24)\end{array}$ & $\begin{array}{l}12.00 \\
(3.46)\end{array}$ & $\begin{array}{c}9.67 \\
(3.11)\end{array}$ \\
\hline 100 & $\begin{array}{c}2.33 \\
(1.53)\end{array}$ & $\begin{array}{c}1.67 \\
(1.29)\end{array}$ & $\begin{array}{c}2.00 \\
(1.41)\end{array}$ & $\begin{array}{c}4.67 \\
(2.16)\end{array}$ & $\begin{array}{l}10.67 \\
(3.27)\end{array}$ & $\begin{array}{l}10.67 \\
(3.27)\end{array}$ \\
\hline SE d & 0.018 & 0.015 & 0.018 & 0.028 & 0.034 & 0.020 \\
\hline CD & 0.038 & 0.032 & 0.037 & 0.058 & 0.072 & 0.041 \\
\hline
\end{tabular}

* Mean of three replications. Values in the parentheses are square root transformed values. In a column, means followed by the common letter(s) are not significant in DMRT @ 5\% level of significance 


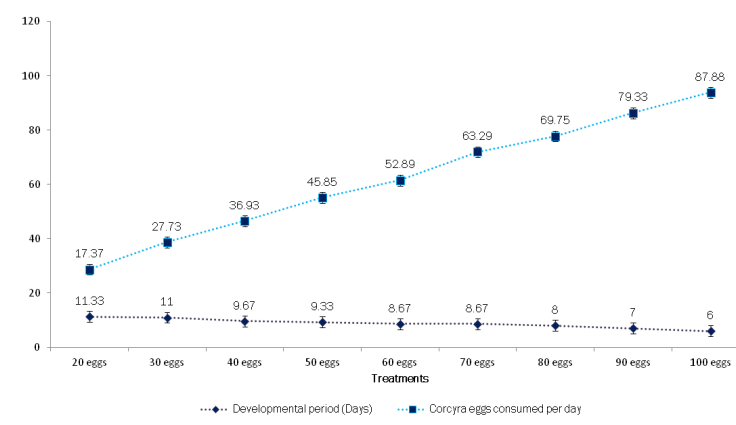

Fig 1. Effect of prey density on the growth of Mallada boninensis

\section{Biological parameters}

Food density had pronounced effects on the biological parameters of $M$. boninensis. The $M$. boninensis have three instar in a grub period and developmental periods also change based on the food density. The first instar grub has duration from 2.33 days (100 eggs / day) to 3.67 days (20 eggs / day). The first instar duration was the same in the treatment 60, 70 and 80 eggs/day with 3.00 days. Similar results were also found in the duration of first instar grub was maximum on $A$. gossypii with 3.54 days and minimum on C. cephalonica with 2.48 days (Guntupalli and Kalyanasundram, 2016). The duration wise there was not much wide variance in high and low density prey in the first instar. The second instar $M$. boninensis having duration from 1.67 days to 3.00 days. Averagely in all treatments other than 90 and 100 eggs/day, the duration of the second instar was 2.33 days. The third instar duration range from 2.00 days (100 eggs /day) to 4.67 days (20 eggs /day)(Table.1) In the third instar M. boninensis was voraciously feeding in Corcyra eggs and there may be variance in the third instar duration of $M$. boninensis. Earlier research indicated the larval duration of a related species Mallada astur (Banks) as 11.6 days (Venkatesan et al., 2002) and Mallada basalis, 11.8 days (Chang, 2000) which are close to our observations. In the present trials, it was noticed that although $M$. boninensis larvae completed development in each of the nine prey densities, an increase in prey density reduced development time and mortality rate.

\section{Duration of developmental stages}

Food density directly affected the $3^{\text {rd }}$ instar larval duration, pupal period, and adult longevity of $M$. boninensis. Increased prey densities reduced the developmental time and mortality rate of $M$. boninensis. (Fig. 2). Maximum duration 20.67 days of grub period was recorded in 20 eggs/ day treatment whereas; minimum duration 10.67 days was recorded in 100 eggs/day treatment. In the case of pupal period, it was shortest in 70 and 80 eggs/day treatment (6.63 and 6.00 days) whereas, the longest pupation period (9.33 days) was recorded in 20 eggs/day treatment. The longest adult longevity was observed in 80, 90 and 100 eggs/day treatments, while shortest adult longevity was noticed in 20, 30 and 40 eggs/day treatments. The results were on par with the results of Nagamallikadevi et al. (2013).

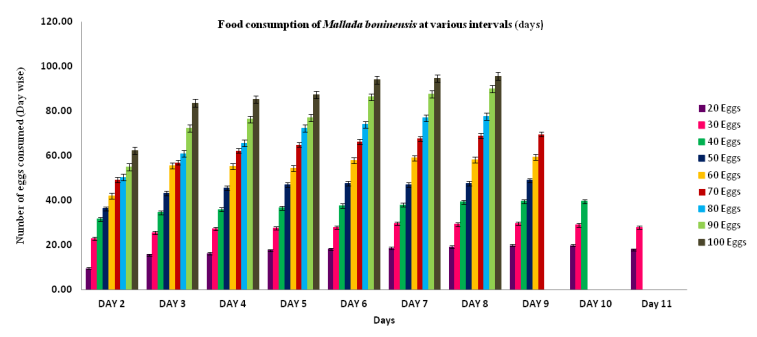

Fig 2. Effect of various food densities on the food consumption of Mallada boninensis at various intervals (days)

They observed that eggs of $C$. cephalonica were superior over all treatments followed by sucking pests for all biological parameters. Larvae survived comparatively more on grubs fed with $C$. cephalonica with 92.8 per cent and larvae survived comparatively more on grubs fed with $C$. cephalonica followed by $A$. gossypii, A. dispersus and A. craccivora. Pupation and adult emergence per cent was more on C. cephalonica (Guntupalli and Kalyanasundram, 2016). This strengthened the present findings. It is widely reported that unsuitable food can extend the pre-imaginal development of chrysopids and decrease the survival, fecundity and longevity of the adults (Zheng et al., 1993). Results of the present studies indicated that prey density had a remarkable effect on consumption rate, development and mortality of $M$. boninensis. Larvae of $M$. boninensis responded to increasing prey densities with increasing food consumption rate. Older larval stages displayed a higher rate of predation than younger ones. The above findings conformed with Zheng et al. (1993) who reported that individual lacewing larvae provided with higher number of Mediterranean flour moth (Anagasta kuehniella) eggs had a significantly higher feeding potential. Hence, Corcyra cephalonica was a suitable host for the mass culturing and development of Mallada boninensis

\section{CONCLUSION}

It was noticed from the data that younger $M$. boninensis grub consumed less food in all prey densities than older grub, probably due to smaller in size larvae having less mobility and prey handling efficiency than a larger sized grub or older grub.

\section{FUNDING AND ACKNOWLEDGMENT}

There is no funding, The authors are grateful to Dean, School of Post Graduate Study (SPGS), Director, Professor and Head, Department of 
Entomology and Central for Plant Protection Studies and Tamil Nadu Agricultural University for the help rendered during my research period.

\section{Ethics statement}

No specific permits were required for the described field studies because no human or animal subjects were involved in this research.

\section{Consent for publication}

All the authors agreed to publish the content.

\section{Competing interests}

There was no conflict of interest in the publication of this content

\section{Data availability}

All the data of this manuscript are included in the M.S. No separate external data source is required. If anything is required from the M.S., certainly, this will be extended by communicating with the corresponding author through corresponding official mail ; elaento@gmail.com

\section{AUTHOR CONTRIBUTIONS}

Research grant- NA; Idea conceptualization - SJN \& SS; Experiments - KE ; Guidance - SJN ; Writingoriginal draft - K.E.; Writing- reviewing \& editing - KE\&SJN

\section{REFERENCES}

Chang, C. P. 2000. Investigation on the Life History of Mallada basalis (Walker) (Neuroptera: Chrysopidae) and the Effects of Temperatures on Its Development. Chinese J. Entomol., 20: 73-87.

Coppel, H.C. and Mertins, J.W. 1977. Biological Insect Pest Suppression. Springer, Berlin.

Elango, K. and Sridharan, S. 2018. Predatory potential of green lacewing, Chrysoperla zastrowi sillemi (Esben-Petersen)(Neuroptera: Chrysopidae) on pomegranate aphid Aphis punicae Passerini (Homoptera: Aphididae), J. Biol. Control., 31: 246248.
Hassanpour, M., Gadir, N.G., Jafar, M. and Annie, E., 2009. Functional response of differentlarval instars of the green lacewing, Chrysoperla carnea (Neuroptera: Chrysopidae), to the twospotted spider mite, Tetranychus urticae (Acari: Tetranychidae). Int. J. Fd, Agric. Environ., 7: 424428.

Klingen, I., Johansen, N.S. And Hofswang, T., 2009. The predation of Chrysoperla carnea (Neuroptera: Chrysopidae) on eggs and larvae of Mamestra brassicae (Lepidoptera: Noctuidae). J. appl. Ent., 120:363-367.

Mcewen, P. K., New, T. R., and Whittington, A. (Eds.). 2001. Lacewings in the Crop Environment. Cambridge University Press, Cambridge, UK, 546 p.

Nagamallikadevi, M., Undirwade, D. B., Nagendra Reddy, B., Ramadevi, A. and Srasvankumar, G. 2013. Biology of Mallada boninensis (Okamoto) [Chrysopidae: Neuroptera] on aphids and neonate noctuids. Biosci. Trends., 6: 827-830.

Nehare, S.K., Deotale, V.Y., Deotale, R.O. and Dawane, P.N. 2004. Biology and predatory potential of Mallada boninensis (Okamoto) against sucking pests. J. Soils Crop., 14 (2): 427-432

Riddick, E. W. 2009. Benefits and limitations of factitious prey and artificial diets on life parameters of predatory beetles, bugs, and lacewings: A minireview. Biocontrol., 54: 325-339.

Sravanthi, G. and Kalyanasundaram, M., 2016. Biology of Mallada boninensis (okamato)(Neuroptera: Chrysopidae) on different larval artificial diet. Current Biotica., 9 (4): 366-372.

Syed, A. N., Ashfaq, M. and Ahmas, S. 2008. Comparative effect of various diets on development of Chrysoperla carnea. Int. J. Agric. Biol., 10: 728-730

Venkatesan, T., Singh, S.P., Jalali, S.K. and Sadhana, P. 2002. Rearing of Mallada astur (Banks) (Neuroptera: Chrysopidae) on a semi-synthetic diet. Pest Manage. Hort. Ecosyst., 8(2): 121-125.

Zheng, Y., Hagen, K. S. Daane, K. M. and Mittler, T. E. 1993. Influence of larval dietary supply on the food consumption, food utilization efficiency, growth and development of lacewing Chrysoperla carnea. Entomol. Exp. Appl., 67:1-7.s 